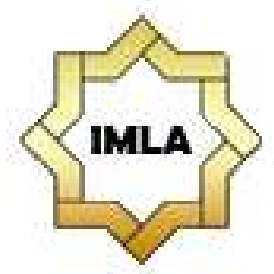

Al-Ta'rib
Jurnal Ilmiah Program Studi Pendidikan Bahasa Arab
IAIN Palangka Raya
Vol. 9, No. 1, June 2021, 49-66
p-ISSN 2354-5887 | e-ISSN 2655-5867
https://doi.org/10.23971/altarib.v9i1.2659

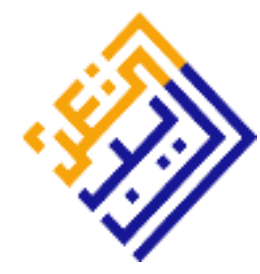

\title{
THE CLARITY AND LEGIBILITY OF STUDENTS' TRANSLATION OF ARABIC - INDONESIAN OFFICIAL TEXT
}

\author{
Deni Maulana ${ }^{1}$, Anwar Sanusi ${ }^{2}$, \\ 1,2Universitas Pendidikan Indonesia, Indonesia \\ E-mail: denimaulana93@upi.edu
}

\begin{abstract}
Assessment of the quality of translation is one of the important activities in translation. The translation assessment can be seen from three aspects: accuracy, clarity, and naturalness. This study aims to reveal the accuracy and fatigue of the translation results of students' Arabic-Indonesian official manuscripts, considering that researchers rarely touch the spiciness aspect than the translation's accuracy and reasonableness. This research uses the descriptive analysis method and content analysis model. The research sample is six graduate students in Arabic Language Education at the Indonesia University of Education. The data collection techniques used were observation, interviews, documentation, and questionnaires. From the results of this study, the researchers obtained several findings, namely: first, the level of mastery was very high, spread as many as eight data (44.4\%), the moderate level of intelligence was spread as many as six data (33.3\%), and the level of intelligence lacked as many as four data. (22.2\%). Second, the level of fatigue in the translation of the official text for high levels of friction is as many as ten data (55.5\%), there are five data (27.7\%) for moderate fatigue, and three data (16.6\%) is less tired. So, from the results of this study, it is concluded that fatigue dominates as much as ten data (55.5\%) compared to the very high level of mastery where there are only eight data (44.4\%).
\end{abstract}

Keywords: legibility; clarity; translation; official texts

\section{Abstrak}

Penilaian kualitas penerjemahan merupakan salah satu aktivitas penting dalam penerjemahan. Penilaian terjemahan bisa dilihat dari tiga aspek yaitu aspek keakuratan (accuracy), ketedasan (clarity), dan kewajaran (naturalness). Penelitian ini bertujuan untuk mengungkap ketedasan dan kejelahan hasil terjemahan naskah resmi Arab-Indonesia mahasiswa mengingat aspek ketedasan masih jarang disentuh oleh para peneliti jika dibandingkan dengan keakuratan dan kewajaran dalam terjemahan. Penelitian ini menggunakan metode analisis deskriptif serta model analisis isi dengan sampel penelitian adalah enam mahasiswa pascasarjana di Pendidikan Bahasa Arab di Universitas Pendidikan Indonesia. Adapun teknik pengumpulan data yang digunakan adalah observasi, wawancara, dokumentasi, dan angket. Dari hasil penelitian ini, peneliti memperoleh beberapa temuan yakni: 
pertama, tingkat ketedasan sangat tinggi tersebar sebanyak delapan data $(44,4 \%)$, tingkat ketedasan sedang tersebar sebanyak enam data (33,3\%), dan tingkat ketedasan kurang terdapat sebanyak empat data (22,2\%). Kedua, tingkat kejelahan penerjemahan teks resmi untuk tingat kejelahan tinggi terdapat sebanyak sepuluh data (55,5\%), tingkat kejelahan sedang terdapat sebanyak lima data $(27,7 \%)$, dan tingkat kejelahan kurang terdapat sebanyak tiga data $(16,6 \%)$. Jadi, dari hasil penelitian ini, disimpulkan bahwa tingkat kejelahan mendominasi sebanyak sepuluh data (55,5\%) jika dibandingkan tingkat ketedasan sangat tinggi yang hanya terdapat sebanya delapan data $(44,4 \%)$.

Kata Kunci: kejelahan; ketedasan; terjemah teks resmi

\section{Introduction}

In this globalization era, the number of information media using translation increases, but an increase in translation quality does not support it. Translation activities are complex activities that require accuracy because acceptable translation depends on the quality of the translation (Iskandar, 2016).

Further, Ardi (2016) adds that translation is one of the most appropriate and inexpensive solutions in accelerating science and technology progress in developing countries. However, translation is not easy. The difference in terms of the system and structure of the source language (SL) and the target language (TL) and the cultural aspects are often the sources of problems for translators. Therefore, translation activities require the translator's ability to solve those problems in transferring messages from SL to TL.

Dhyaningrum \& Nababan (2016) state that translating is not just translating the text from the source language to the target language. Good translation skills are also inseparable from the translator's skills to divert the meaning and aesthetic elements. Raoufkazemi et al. (2020) added that accurate translation is an inherently interdisciplinary effort. Many references can be used when we want to understand the meaning of a translation. In general, translation can be interpreted to transfer messages from SL to TL (Maulana, 2019; Maulana, 2019).

Also, Larson (1998) states that translation activities are generally defined as the activities to transfer the source language (SL) into the target language (TL). In translation, the aspects of accuracy, clarity, and naturalness must be included in transferring the messages from SL to TL. Clarity is essential because it affects the legibility of the translated text. From the translated narrative, readability and ease of understanding emerge (Al Farisi, 2018; Abualadas, 2020). The best translation results are those that have a high level of accuracy, clarity, and naturalness. However, considering various aspects, sometimes, in practice, it isn't easy to produce a perfect translation. It is because translators are often faced with the choice to prioritize one aspect and sacrifice another.

The first aspect is accuracy related to the equivalent meaning between the source language (SL) and the target language (TL). The message translated must be conveyed accurately and has an equivalent meaning. The very purpose is not only in terms of form but also messages and ideas and does not contain distortion of meaning (Yousofi, 2014; Sutantohadi, 2017; Sanusi, 2019). The second aspect is that acceptability is also an essential factor determining the quality of the translation results. The acceptability aspect is the degree of naturalness of a 
translated text toward the target language's norms, culture, and rules. To achieve translation results with a high level of acceptability, a translator must have good competence related to the language and culture of the target language to be able to adjust between the grammar and cultural norms of the source language with the grammar and cultural norms of the target language (Stark \& Kussmaul, 1997; Newmark, 1981; Hatmiati \& Husin, 2018).

In translation, a translator must pay attention to accuracy and acceptability and pay attention to the elements to the so-called Sakri (1994) as clarity and legibility. Clarity is related to linguistic aspects; the readability of language is determined by choice of words, sentence structure, paragraph structure, and other grammatical elements. Meanwhile, legibility is related to nonlinguistic aspects and grammatical legibility, determined by letter size, line density, splash width, and other visual arts.

Therefore, this study focused on analyzing and determining the level of clarity and legibility of translation by considering the criteria of readability of the source language translated into the target language. The clarity aspect is fundamental in evaluating the quality of the translation. According to Al-Farisi (2017), the clarity aspect is related to how difficult/easy it is for the readers to understand the message that has been expressed from the source language into the target language. In other words, the clarity aspect is related to the readability of a translated text. In line with this, Harry McLaghlin, cited by Zamanian, \& Heydari (2012), emphasizes that readability refers to the extent to which a particular group of people finds unique reading material exciting and understandable. Besides, in translating a text, whether it is a holy text or an official text, one should choose the best way to solve the text by selecting the type of text to be translated (Abidin et al., 2020).

Several factors might affect the readability level of a translated text, Richards \& Richard, (2002). namely, the average length of sentences, the number of new words, and the grammatical complexity of the language used. The above explanation shows that to achieve a high level of readability in the TL translation text, the translator must pay attention to the linguistic elements in the SL text. Thus, all factors in the SL text that will be transferred to TL, including the selection of diction and sentence structure, will affect the translation's readability.

Several formulas to determine the level of readability in a translated text could be divided into three categories (Nababan \& Nuraeni, 2012), namely high, medium, and low readability. A high readability level can be seen if the readers can easily understand words, technical terms, phrases, clauses, sentences of the translated text. Meanwhile, the reader can see a medium level of readability if the reader could understand the translated text. Still, there are specific passages that must be read more than once to understand the translation. Translations that are difficult for readers to understand are at a low level of readability.

Apart from the clarity aspect, the translator must pay attention to the legibility aspect. In the process of translating text from the SL (Arabic) into TL (Indonesian), translators frequently too focus on thinking about how to achieve a good quality translation, so they don't pay much attention to the aspect of legibility, such as; grammatical legibility, which is determined by lowercase, line 
density, margins, functionality, and other visual elements that are not relevant to Indonesian / POEBI grammar.

Consequently, the translation results seem to balance the translation quality and the proper writing procedures by what the translator has transferred from SL into TL (Indonesian). Thus, clarity and legibility have an inherent relationship that cannot be separated in translating activities.

Moreover, translating becomes a subject taught by each foreign language study program to the students, mainly Arabic education students of Indonesia University of Education (IUE) Bandung. According to Syihabudin, quoted by Alawiyah et al. (2016) the Alawiyah, et al. translation activity given in the form of a subject in a college aims to equip students with basic skills in translating so that it can help and facilitate the students in exploring other relevant issues.

In fact, in the master program of the Arabic education department IUE, translating activities are carried out not only in translation subjects but also in relevant subjects. The intensity of solving activities increases, mainly when the students write their theses written in Arabic and articles, for instance, translating citations from Arabic books into Indonesian as compulsory references.

Regarding the study on translation as a product, there are several previous studies conducted. Maulana \& Sanusi (2020) conducted a survey focused on verb errors made by the students in translating. The results of their research revealed that the students made errors in translating text using past verbs (fi'il mädii) 14 (11\%), 111 (89\%) errors related to non-past verbs (fi'il mudāri '). Moreover, the students feel difficult to choose the appropriate meaning when translating the text from Indonesian to Arabic.

Sanusi (2019) conducted a study on the quality of students' qirā'ah text translations regarding translating texts. This study revealed that accuracy could be considered the suitability or accuracy of the messages conveyed between the source language and the target language.

Syihabuddin (2016), in his study, discussed the translation of holy texts in which he said that the terms ulū al-'ilm, ulū al-abșār, ulū al-nuhā, and ulū al-albāb are translated into Indonesian in various ways with different levels of accuracy. Ulū al-albāb and ulū al-nuhā are translated quite precisely, ulū al-'ilm is translated correctly, and ulū al-abșār are mistranslated. The story of accuracy is influenced by the translation techniques used, cultural differences, and inaccuracies in expressing lexical meanings. The four terms indicate semantic relations ranging from the most specific and functional to the most general, namely from ulū alalbāb, ulū al-nuhā, ulū al-abșār, to ulū al-'ilm.

Meanwhile, Al Farisi (2020), in the holy text of the Koran, kinayah speech acts are often a complex problem in the translation process. This is because the domestication trend presents the accuracy and transparency of the kinayah verses in the translation. The translation techniques to both translations are made with a single procedure and the couplet, triplet, and quartet procedures. The stanza procedure that combines literal and amplification techniques provides a good quality translation of kinayah verses. The literal technique's application presents the primary meaning of the kinayah verses accurately, while the application of the amplification technique transparently presents the secondary importance. 
Regarding the holy texts, Mukhlis \& Nasimah (2020), in their study, explained that the level of translation of a text could be measured based on the characteristics of the genre of the text. The readers of the Bible and the Qur'an have literary values descended from generation to generation. The high aesthetic elements contained in both raise significant constraints compared to standard descriptive texts.

Al Farisi (2017) researched the accuracy of the translation of imperative verses. The translation speed is inseparable from the translation techniques and procedures applied in handling micro translation units. A couplet procedure that combines literal style and amplification technique can provide acceptable translation subtlety.

These various studies still have gaps that have not been examined related to the translation of the official texts. Based on this gap, this study focused on the clarity and legibility of students' translation of Arabic - Indonesia official texts.

\section{Methods}

This study used a qualitative descriptive method with a content analysis model. Content analysis is a research technique for making replicable inferences. The validity of the data was carried out by considering the context. The research approach and method used in this study were deemed relevant because this study focused on research documents in translation works/papers.

This study was aimed to reveal the clarity and legibility of translated text of official documents written by graduate students of the Arabic Education Department, Indonesia University of Education. This is because students know that they can translate documents related to the lessons and translate official documents. The data in this study were in the form of translation results of graduate students of IUE Arabic Language Education (ALE). Six graduate students were chosen as the participants in this study. A purposive sampling technique was used in this study, meaning that the study's determination is based on specific considerations and criteria according to the study's objective. The translated texts obtained by conducting a translation test were collected, and finally, there were six translated texts. After analyzing the six texts, the researchers found 18 data related to clarity and legibility.

The translation results were used as data analysis. In the translation process, the participants were allowed to use dictionaries and books related to Arabic-Indonesian translation. Analysis of the translation results was carried out by comparing the translation results of IUE, ALE graduate students with the translation results from experts in Indonesian-Arabic translation.

The instrument to determine the level of clarity and legibility in a translated text is adapted from Nababan, \& Nuraeni (2012), as follows.

Table 1.

Scale and Description for Clarity/Readability Instrument

\begin{tabular}{lccc}
\hline $\begin{array}{l}\text { Translation } \\
\text { Category }\end{array}$ & Score & \multicolumn{2}{c}{ Qualitative Parameter } \\
\hline High Clarity & 3 & The & readers can easily understand \\
\multicolumn{2}{c}{$\begin{array}{l}\text { Jurnal Ilmiah Program Studi Pendidikan Bahasa Arab IAIN Palangka Raya Vol. 9, No. } 1 \text { /49-66 } \\
\text { Al-Ta'rib | p-ISSN 2354-5887 | e-ISSN 2655-5867 }\end{array}$}
\end{tabular}




\begin{tabular}{ccc}
\hline Level (HCL) & $\begin{array}{l}\text { technical terms, phrases, clauses, sentences, or } \\
\text { translated texts. } \\
\text { In general, the readers could understand }\end{array}$ \\
$\begin{array}{c}\text { Moderate } \\
\text { Clarity Level } \\
\text { (MCL) }\end{array}$ & $\begin{array}{l}\text { the translation, but there are specific passages } \\
\text { that must be read more than once to understand } \\
\text { the translation. }\end{array}$ \\
$\begin{array}{c}\text { Low Clarity } \\
\text { Level (LCL) }\end{array}$ & 1 & $\begin{array}{c}\text { The readers are difficult to understand } \\
\text { the translation. }\end{array}$ \\
\hline
\end{tabular}

Table 2.

Scale and Description for Legibility Instrument

\begin{tabular}{|c|c|c|}
\hline $\begin{array}{l}\text { Translation } \\
\text { Category }\end{array}$ & Score & Qualitative Parameter \\
\hline $\begin{array}{l}\text { High Legibility } \\
\text { Level (HLL) }\end{array}$ & 3 & $\begin{array}{l}\text { Grammatical legibility is determined by } \\
\text { letter size, line density, flash width, and other } \\
\text { visual elements. }\end{array}$ \\
\hline $\begin{array}{l}\text { Moderate } \\
\text { Legibility Level } \\
\text { (MLL) }\end{array}$ & 2 & $\begin{array}{l}\text { This legibility is viewed from the spacing } \\
\text { between letters, spacing between words, line } \\
\text { spacing of the letter arrangement, and the type } \\
\text { of letter selected. }\end{array}$ \\
\hline $\begin{array}{l}\text { Low Legibility } \\
\text { Level (LLL) }\end{array}$ & 1 & $\begin{array}{l}\text { Unclear letter capitalization, spacing } \\
\text { between words, and heeding punctuation. }\end{array}$ \\
\hline
\end{tabular}

After getting the percentage of clarity and legibility in the translation, the researchers concluded the graduate students' translation of Arabic-Indonesian official text.

\section{Results and Discussion}

Whether we realize it or not, translation activity not only moves text from one language to another, but it is related to presenting an idea. In assessing the quality of translation, readability is associated with the clarity and legibility of the translation, which is influenced by sentence construction length.

Readability refers to the ease of written material to be read and understood (Richards \& Richard, 2002). In line with Richards, Sakri Sakri (2003)states that readability is the degree of ease of writing to be read and understood its meaning. Based on these two definitions, it is clear that readability refers to the reader as the subject who determines a text's readability. To identify the accuracy of the graduate students' translation, the researchers used experts' translation results as a comparison. The following is the Arabic -Indonesian translation result from the translation expert. 


\section{Picture 1.}

\section{Picture of Document}

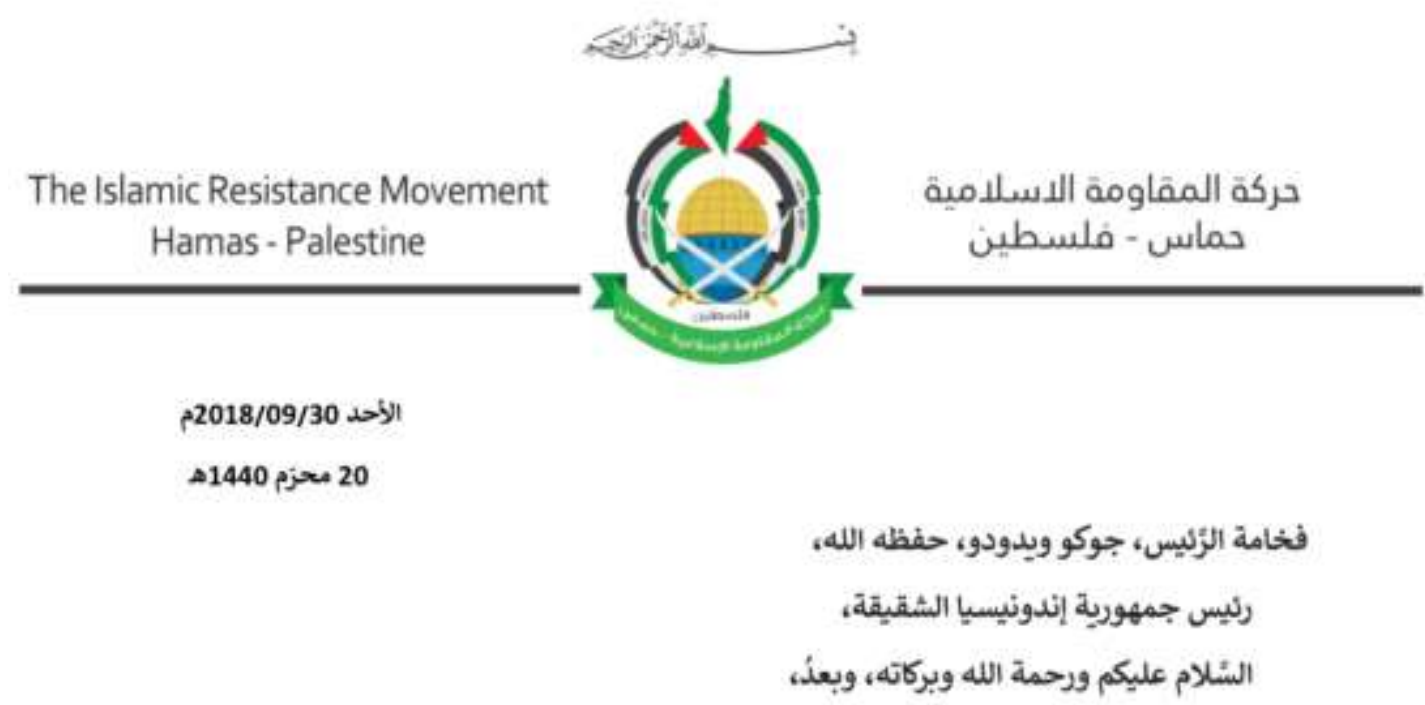

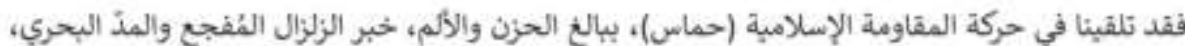

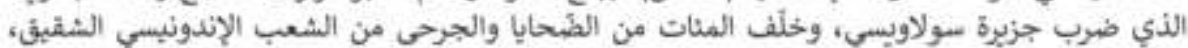
وأضراراً في المباني وألمتلكتات والمرافق العاثة.

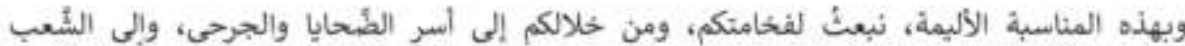

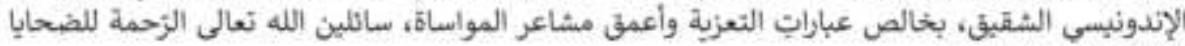

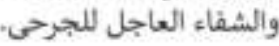

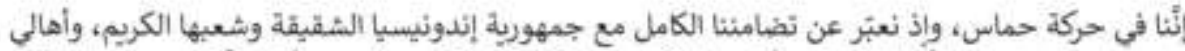

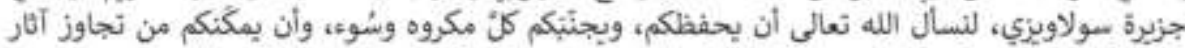

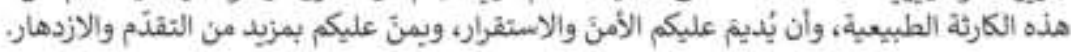

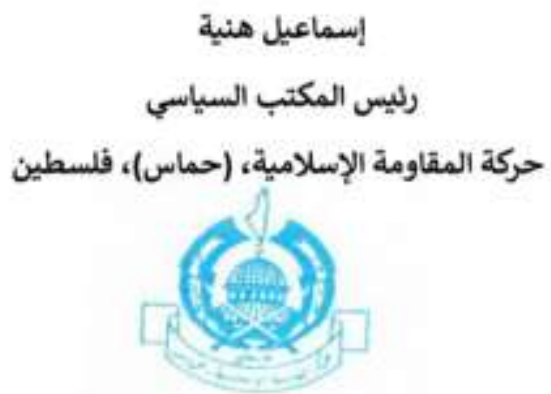

The translation of the official document 


\author{
Harakat al-Muqāwamah al-'Islāmiyyah
}

HAMAS - PALESTINA

Minggu, 30 September 2018

20 Muharram $1440 \mathrm{H}$

\title{
Yth. Presiden Republik Indonesia, Joko Widodo
}

Assalamu'alaikum wr. wb.

Kami, selaku Harakat al-Muqāwamah al-'Islāmiyyah (Hamas) telah menerima kabar lara yang mendalam atas bencana gempa bumi dan tsunami yang menimpa Pulau Sulawesi. Ratusan jiwa rakyat Indonesia terluka dan meninggal dunia, serta kerusakan bangunan dan fasilitas umum.

Pada kesempatan ini, Kami, melalui Bapak Presiden, menyampaikan belasungkawa dan simpati sedalam-dalamnya kepada keluarga para korban bencana dan mereka yang terluka, serta seluruh masyarakat Indonesia. Semoga Allah Swt mengampuni para korban yang meninggal dan menyembuhkan secepatnya korban yang terluka.

Kami selaku gerakan Hamas menjunjung rasa solidaritas yang tinggi terhadap persaudaraan dengan masyarakat Indonesia, khususnya masyarakat Pulau Sulawesi. Semoga Allah Swt melindungi semua, serta menjauhkannya dari segala kejahatan, mampu mengatasi dampak dari bencana alam ini, menjaga keamanan dan stabilitas, serta semoga lebih maju dan makmur.

\section{Ismail Haniyah}

\section{Kepala Bidang Politik}

\section{Harakat al-Muqāwamah al-'Islāmiyyah (Hamas), Palestina}

\section{The Clarity of Official Text Translation}

In terms of the readability of a translated text, according to Sakri (2003), there are two terms related to the readability of a text, namely clarity, and legibility. Clarity is related to language readability determined by word choice, sentence construction, paragraph arrangement, and other grammatical elements. Then, legibility has something to do with the letters' readability, including upper/lowercase letters, line density, stroke width, layout, typography, and other design elements.

In this study, the researchers took six data, each datum containing three findings. Thus, if accumulated into 18 findings, those data are part of sentences in the official document's translation text. This study's findings indicate that the 
translation results of the official document have a high degree of clarity, namely $44.4 \%$.

Table 3.

The Clarity of Official Text Translation

\begin{tabular}{cccccc}
\hline & & \multicolumn{3}{c}{ Clarity Categories } & \\
\cline { 3 - 5 } No & $\begin{array}{c}\text { The Result of } \\
\text { Respondents }\end{array}$ & $\begin{array}{c}\text { HCL } \\
\text { (High } \\
\text { clarity } \\
\text { level) }\end{array}$ & $\begin{array}{c}\text { MCL } \\
\text { (Moderate } \\
\text { clarity } \\
\text { level) }\end{array}$ & $\begin{array}{c}\text { LCL (Low } \\
\text { clarity } \\
\text { level) }\end{array}$ & Measurement \\
\hline 1 & 8 & $44,4 \%$ & & & Total: 18 data \\
2 & 6 & & $33,3 \%$ & & \\
\hline 3 & 4 & & & $22,2 \%$ & Percentage: $\mathbf{1 0 0} \%$ \\
\hline
\end{tabular}

\section{Clarity}

First, a high level of clarity can be seen if the word, technical term, phrase, clause, sentence, or translation text could be easily understood. In line with the research conducted by Al Farisi (2017) regarding sharpness, the aspect of clarity is related to the readability of the translation language, which includes the elements present in it, such as thought flow, sentence construction, and other grammatical features. In this study, eight data were identified.

Tabel 4.

Example 1

\begin{tabular}{|c|c|}
\hline Source Language (SL) & Target Language (TL) \\
\hline 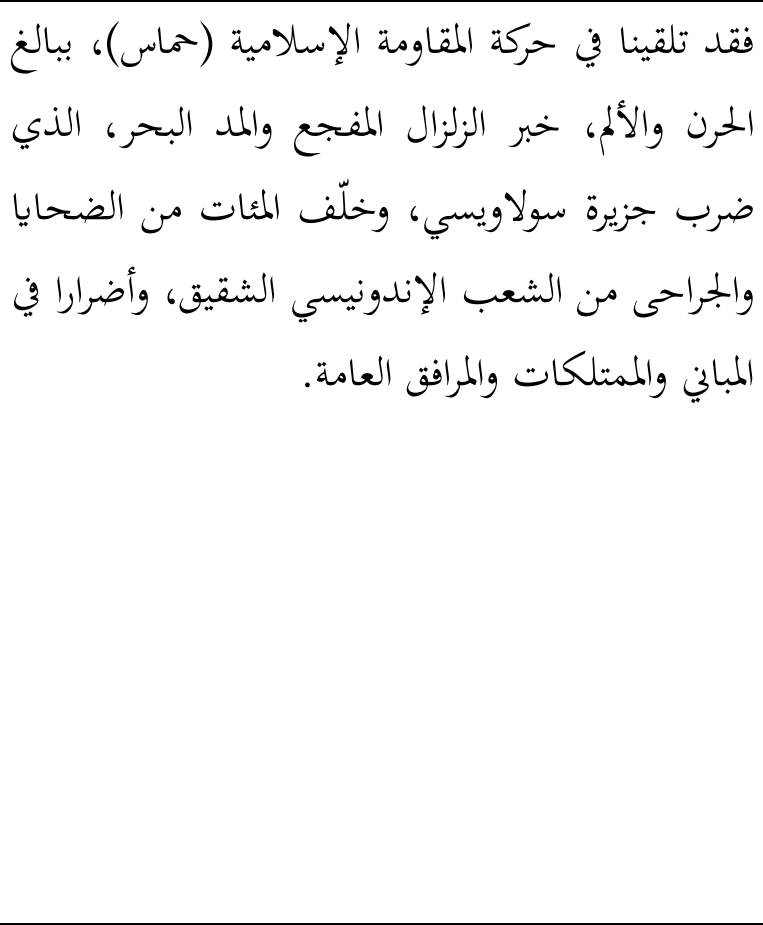 & $\begin{array}{l}\text { Kami dari gerakan HAMAS telah } \\
\text { menerima berita sedih dan } \\
\text { menyakitkan, tentang terjadinya } \\
\text { gempa secara tiba-tiba dan luapan } \\
\text { air laut yang menerjang Pulau } \\
\text { Sulawesi, yang menyebabkan } \\
\text { ratusan korban meninggal dan } \\
\text { terluka dari warga Indonesia serta } \\
\text { kerusakan berbagai bangunan, } \\
\text { properti, dan fasilitas umum. } \\
\text { (We from the HAMAS movement } \\
\text { have received sad and painful news, } \\
\text { about an abrupt earthquake and an } \\
\text { overflow of sea water that hit the } \\
\text { island of Sulawesi, causing } \\
\text { hundreds of deaths and injuries } \\
\text { from Indonesian citizens as well as } \\
\text { damage to various buildings, }\end{array}$ \\
\hline
\end{tabular}


The above translation is translated in good/high clarity. Grammatically, it doesn't matter, and the meaning could be caught easily. Also, the phrase بالغ الحرن والألم has been translated telah menerima berita sedih dan menyakitkan. The translation is considered innovative but needs improvement because translating الحرن والألم means sedih dan menyakitkan (sad and unfortunate). The translation is already creative, but it would be more appropriate to translate it into telah menerima kabar lara yang mendalam (have received sad news) (addition technique). This is done to clarify the author's message of the source text.

The researchers offer a translation, namely; "Kami, selaku Harakat alMuqāwamah al-'Islāmiyyah (Hamas) telah menerima kabar lara yang mendalam atas bencana gempa bumi dan tsunami yang menimpa Pulau Sulawesi. Ratusan jiwa rakyat Indonesia terluka dan meninggal dunia, serta kerusakan bangunan dan fasilitas umum." (We, as the people of Harakat al-Muqāwamah al-'Islämiyyah (Hamas) have received painful news about the earthquake and tsunami that hit Sulawesi Island. Hundreds of Indonesian were injured and died, as well as damage to buildings and public facilities

Second, medium clarity level is that the reader could generally understand the translation. Still, there are specific passages that must be read more than once to understand the translation. In this study, six data were identified.

Table 5.

\section{Example 2}

\begin{tabular}{|c|c|}
\hline Source Language (SL) & Target Language (TL) \\
\hline 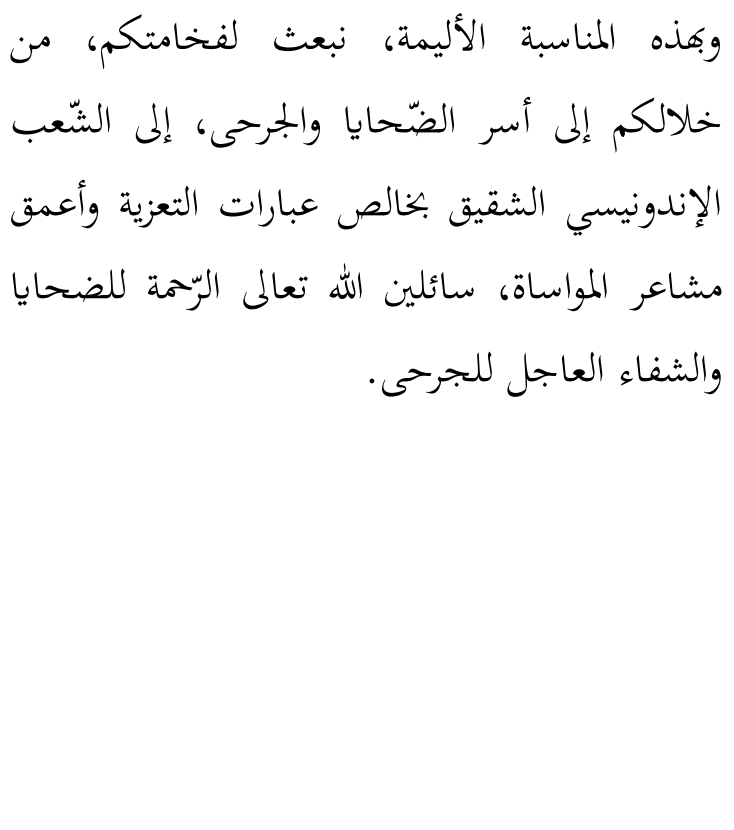 & $\begin{array}{l}\text { Dikesempatan yang menyedihkan ini, } \\
\text { kami mengirim ucapan belasungkawa } \\
\text { yang tulus melalui pimpinan kalian } \\
\text { untuk keluarga korban, dan untuk } \\
\text { saudara-saudara penduduk Indonesia, } \\
\text { kami meminta rahmat kepada Allah } \\
\text { untuk para korban serta semoga Allah } \\
\text { memberi kesembuhan bagi korban } \\
\text { luka-luka. } \\
\text { (On this sad occasion, we send our } \\
\text { sincere condolences through your } \\
\text { leader to the families of the victims } \\
\text { and the brothers and sisters of } \\
\text { Indonesian, we pray to Allah for mercy } \\
\text { for the victims, and may Allah give } \\
\text { healing to the injured victims) }\end{array}$ \\
\hline
\end{tabular}


Based on the above translation, the translation has a medium level of clarity. This is because some are less sharp, for example, from the phrase which means 'pemimpin kalian' (your leader). However, the phrase's translation would be more correct if translated as 'bapak presiden' (Mr. President) (common equivalence technique). It might be because there are people who have less knowledge about clarity, such as the phrase 'pemimpin kalian' (your leader) should be translated as 'bapak presiden' (Mr. President). The researchers offer a translation; "Pada kesempatan ini, Kami, melalui Bapak Presiden, menyampaikan belasungkawa dan simpati sedalam-dalamnya kepada keluarga para korban bencana dan mereka yang terluka, serta seluruh masyarakat Indonesia. Semoga Allah Swt mengampuni para korban yang meninggal dan menyembuhkan secepatnya korban yang terluka." (On this occasion, we, through Mr. President, would like to extend our deepest condolences and sympathy to the families of the victims of the disaster and those who were injured, as well as all Indonesian people. May Allah SWT forgives the victims who died and heal the wounded victims as soon as possible).

Third, the low clarity occurs because the translation is difficult to be understood by the readers. In this study, four data were identified.

Table 6.

Example 3

\begin{tabular}{|c|c|}
\hline Source Language (SL) & Target Language (TL) \\
\hline 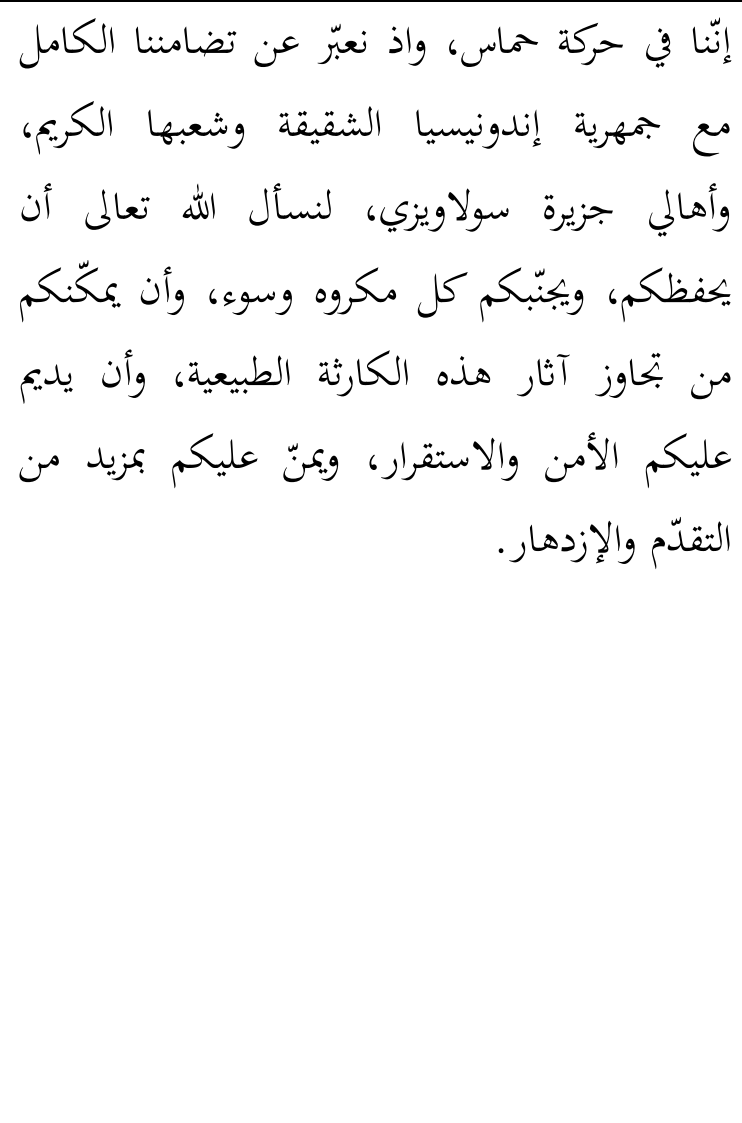 & $\begin{array}{l}\text { Meski berada di Hamas, kami } \\
\text { mengungkapkan solidaritas penuh } \\
\text { kepada Negara Kesatuan Republik } \\
\text { Indonesia dan penduduknya yang mulia, } \\
\text { khususnya penduduk Pulau Sulawesi. } \\
\text { Mari memohon kepada Allah SWT untuk } \\
\text { melindungi rakyat Indonesia dari segala } \\
\text { keburukan; menguatkan Bapak Presiden } \\
\text { agar mampu mengatasi akibat dari } \\
\text { bencana alam juga melestarikan } \\
\text { keamanan dan stabilitas negara; dan } \\
\text { mengaruniakan kemajuan } \\
\text { kemakmuran bagi rakyat Indonesia. } \\
\text { (Even though we are at Hamas, we } \\
\text { express our full solidarity with the } \\
\text { Unitary State of the Republic of } \\
\text { Indonesia and its noble people, } \\
\text { especially the people of Sulawesi Island. } \\
\text { Let's pray to Allah SWT to protect the } \\
\text { Indonesian people from all evil; } \\
\text { strengthen Mr. President to be able to } \\
\text { overcome the impacts of natural }\end{array}$ \\
\hline
\end{tabular}


disasters as well as to preserve the country's security and stability; and bestow progress and prosperity to the Indonesian people)

In the above translation, it cannot be read clearly. It could be said that there are several errors, namely the redirection accuracy of the message, the mistake of translating technical terms, and grammatical errors. On the phrase, إنّا في حركة حماس ، واذ means Meski berada di Hamas, kami mengungkapkan solidaritas penuh kepada Negara Kesatuan Republik Indonesia dan penduduknya yang mulia, khususnya penduduk Pulau Sulawesi. (Even though we are at Hamas, we express our full solidarity with the Unitary State of the Republic of Indonesia and its noble people, especially the people of Sulawesi Island.). (Literal technique). The message in the translation has not been delivered.

The researchers offer a translation, namely 'Kami selaku gerakan Hamas menjunjung rasa solidaritas yang tinggi terhadap persaudaraan dengan masyarakat Indonesia, khususnya masyarakat Pulau Sulawesi. Semoga Allah Swt melindungi semua, serta menjauhkannya dari segala kejahatan, mampu mengatasi dampak dari bencana alam ini, menjaga keamanan dan stabilitas, serta semoga lebih maju dan makmur' (We, as the Hamas movement, uphold a high sense of solidarity with the Indonesian people, especially the people of Sulawesi Island. May Allah SWT protect all, and keep them away from all evil, be able to overcome the effects of this natural disaster, maintain security and stability, and hopefully be more advanced and prosperous)

\section{The Legibility of Official Text Translation}

Regarding the readability of a text, another important aspect besides clarity is legibility. Sakri (2003) states that legibility is related to the readability of letters, including upper / lower case letters, line density, the width of flash, layout, typography, and other elements of design.

Regarding the legibility, the researchers took six data each datum containing three findings. Thus, if accumulated into 18 findings, those data are part of sentences in the official document's translation text. This study's findings indicate that the translation results of the official document have a high degree of legibility, namely 55,5\%.

Table 7.

The Legibility of Official Text Translation

\begin{tabular}{|c|c|c|c|c|c|}
\hline \multirow[b]{2}{*}{ No } & \multirow[b]{2}{*}{$\begin{array}{l}\text { The Result of } \\
\text { Respondents }\end{array}$} & \multicolumn{3}{|c|}{ Legibility Categories } & \multirow[b]{2}{*}{ Measurement } \\
\hline & & $\begin{array}{c}\text { HLL } \\
\text { (High } \\
\text { legibility } \\
\text { level) }\end{array}$ & $\begin{array}{c}\text { MLL } \\
\text { (Moderate } \\
\text { legibility } \\
\text { level) }\end{array}$ & $\begin{array}{c}\text { LLL } \\
\text { (Low } \\
\text { legibility } \\
\text { level) }\end{array}$ & \\
\hline 1 & 10 & $55,5 \%$ & & & \\
\hline 2 & 5 & & $27,7 \%$ & & Total: 18 data \\
\hline 3 & 3 & & & $16,6 \%$ & \\
\hline
\end{tabular}

Jurnal Ilmiah Program Studi Pendidikan Bahasa Arab IAIN Palangka Raya Vol. 9, No. 1 /49-66 Al-Ta'rib | p-ISSN 2354-5887 | e-ISSN 2655-5867 


\begin{tabular}{|c|c|c|c|c|c|}
\hline & Mean & $55.5 \%$ & $27.7 \%$ & $16.6 \%$ & \\
\hline
\end{tabular}

First, high or good legibility could be viewed from the letters' readability, which is determined by the font size, line density, flash width, and other visual elements. In this study, 10 data were identified regarding the legibility aspect.

Table 8.

Example 1

\begin{tabular}{|c|c|}
\hline Source Language (SL) & Target Language (TL) \\
\hline 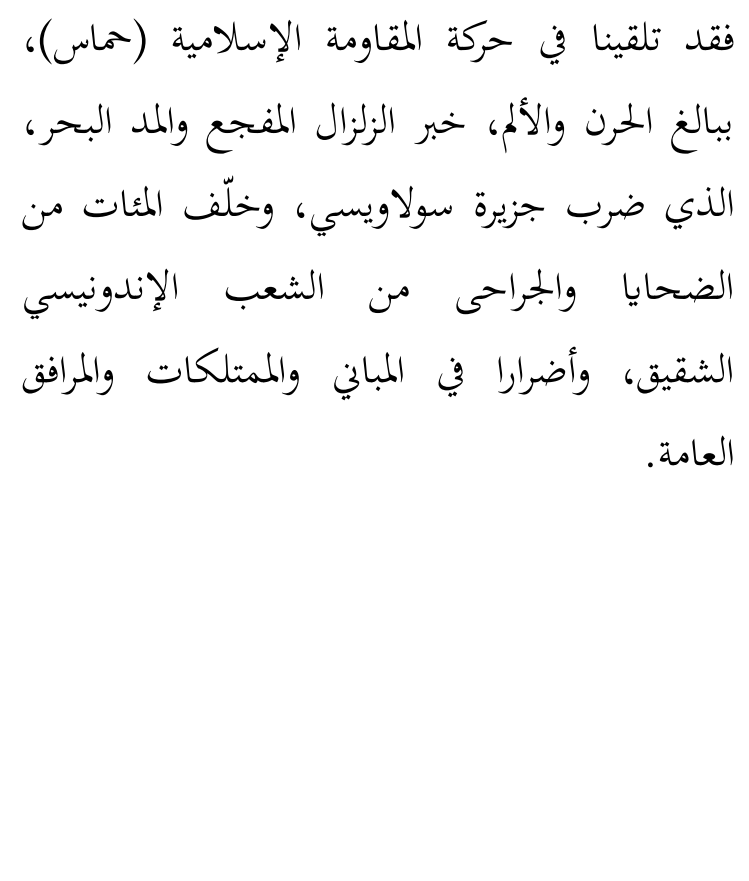 & $\begin{array}{l}\text { Kami dari gerakan HAMAS telah } \\
\text { menerima berita sedih dan menyakitkan, } \\
\text { tentang terjadinya gempa secara tiba- } \\
\text { tiba dan luapan air lautyang menerjang } \\
\text { Pulau Sulawesi, yang menyebabkan } \\
\text { ratusan korban meninggal dan terluka } \\
\text { dari warga Indonesia serta kerusakan } \\
\text { berbagai bangunan, properti, dan } \\
\text { fasilitas umum. } \\
\text { (We from the HAMAS movement have } \\
\text { received sad and painful news, about an } \\
\text { abrupt earthquake and an overflow of } \\
\text { sea water that hit the island of } \\
\text { Sulawesi, causing hundreds of deaths } \\
\text { and injuries from Indonesian citizens as } \\
\text { well as damage to various buildings, } \\
\text { property and public facilities) }\end{array}$ \\
\hline
\end{tabular}

Based on the above data, it could be said that the translation has a high level of legibility. In the above translation, there is the word 'Kami' (We) and the name of the city 'Sulawesi' written in capital letters. However, the term 'Pulau' (island) should be written in lowercase "pulau' (island).

Second, a medium level of legibility could be viewed from the spacing between letters, spacing between words, line spacing of the letter arrangement, and the selected type of font. In this study, the researchers identified five data regarding a low level of legibility.

Table 9.

Example 2

\begin{tabular}{|c|c|}
\hline Source Language (SL) & Target Language (TL) \\
\hline 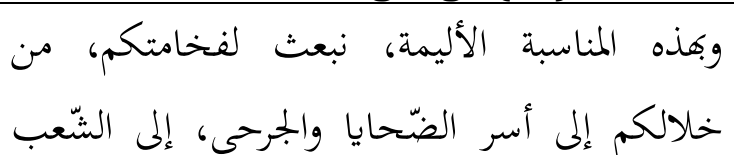 & $\begin{array}{l}\text { Dan pada peristiwa yang memedihkan } \\
\text { ini, kami mengirimkan ucapan } \\
\text { belasungkawa yang tulus dan rasa }\end{array}$ \\
\hline
\end{tabular}




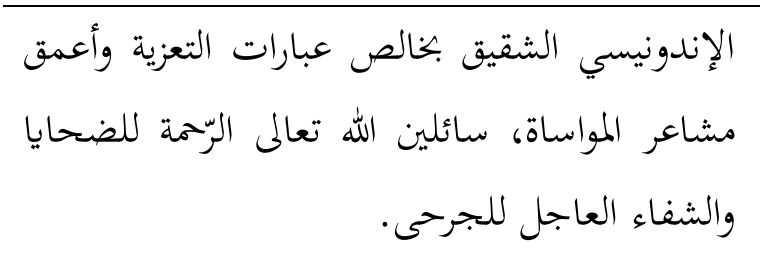

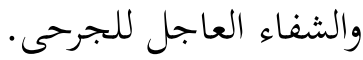

simpati yang terdalam untuk tuan, para keluarga korban dan yang luka-luka, serta warga negara RI. Kami meminta kepada Allah kerahmatan untuk korban dan semoga lekas sembuh bagi yang luka-luka.

(And on this sad event, we send our sincere condolences and deepest sympathy to you, the families of the victims and the injured, and the citizens of the Republic of Indonesia. We ask Allah for mercy for the victims and hopefully a speedy recovery for the wounded).

The above sentence has a medium level of legibility. It might be because, at the beginning of the sentence, there is the word 'Dan' (And). The word 'Dan' should not be used at the beginning of the sentence. The type of letter chosen is not appropriate; the letter ' $R I$ ' should be written as Republik Indonesia (the Republic of Indonesia).

Third, the low legibility level is due to unclear capitalization of letters, spacing between words, and heeding punctuation. In this study, three data were identified.

Table 10.

Example 3

\begin{tabular}{|c|c|}
\hline Source Language (SL) & Target Language (TL) \\
\hline 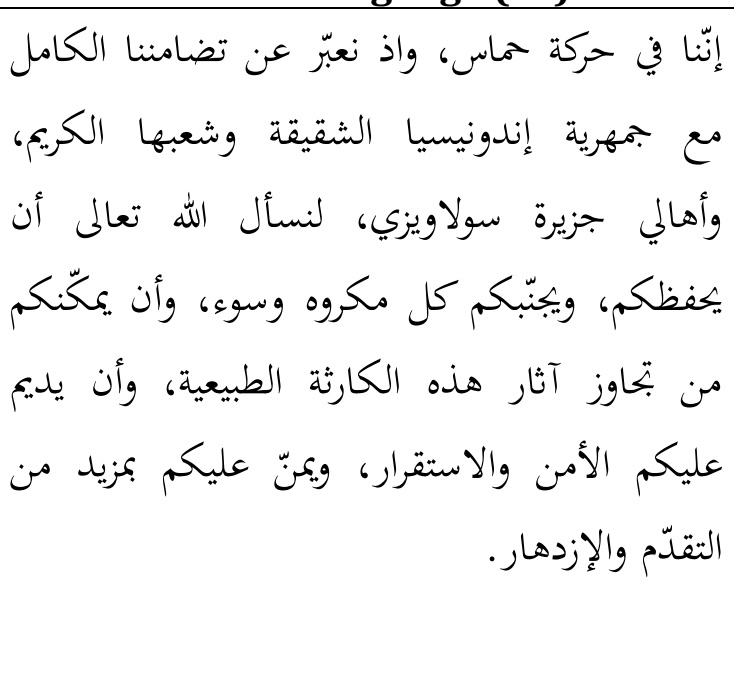 & $\begin{array}{l}\text { Meski berada di Hamas, kami } \\
\text { mengungkapkan solidaritas penuh } \\
\text { kepada Negara Kesatuan Republik } \\
\text { Indonesia dan penduduknya yang } \\
\text { mulia, khususnya penduduk Pulau } \\
\text { Sulawesi. Mari memohon kepada Allah } \\
\text { SWT untuk melindungi rakyat } \\
\text { Indonesia dari segala keburukan; } \\
\text { menguatkan Bapak Presiden agar } \\
\text { mampu mengatasi akibat dari bencana } \\
\text { alam juga melestarikan keamanan dan } \\
\text { stabilitas negara; dan mengaruniakan } \\
\text { kemajuan dan kemakmuran bagi rakyat } \\
\text { Indonesia. }\end{array}$ \\
\hline & \\
\hline
\end{tabular}


express our full solidarity with the

Unitary State of the Republic of Indonesia and its noble people, especially the people of Sulawesi Island. Let's pray to Allah SWT to protect the Indonesian people from all evil; strengthen Mr. President to be able to overcome the impacts of natural disasters as well as to preserve the country's security and stability; and bestow progress and prosperity to the Indonesian people)

The translation of the above sentence has a low level of legibility. It is because the word 'dan' (and) frequently appears. The researchers assume that the data heeded punctuation. The words 'dan' (and) should be replaced with commas (,). Also, it was found that the word 'Pulau' (Island) was written in capital letters. The word 'pulau' should be written in lowercase, 'pulau' (island).

In fact, in the researcher's opinion, this research on the assessment of translation legibility is something new in translation. Because researchers have not found any literature, either national articles or international articles, that discuss translation legibility, this research on the evaluation of translation legibility is present as a novelty about translation.

\section{Conclusions}

Clarity and legibility are part of the quality measurement of the translation related to readability. Based on the results of the analysis of the clarity and legibility of ALE, IUE graduate students' translation of Arabic - Indonesian official document, it could be concluded that a high level of clarity was spread over eight data $(44.4 \%)$, medium level of clarity was spread over six data $(33.3 \%)$, and low level of clarity was spread over four data $(22,2 \%)$. Then, there were three categories regarding the legibility of the translation, namely, high legibility consisting of 10 data (55,5\%), moderate legibility consisting of five data $(27,7 \%)$, and low legibility composed of three data $(16,6 \%)$. Therefore, the dominating level of legibility was 10 data $(55,5 \%)$. Besides, the accuracy of the translated text can be seen from the style of the translation technique. If the translation technique is appropriate, the message will be conveyed to the reader.

Besides, the research results on the translation of clarity and legibility can contribute as a model for evaluating translation, especially in terms of clarity and legibility in translating Arabic into Indonesian. This research, primarily related to sharpness and needs to be followed up, stops at the official text and on the clarity and legibility such as conversations in Arabic films and Indonesian translations.

\section{References}

Abidin, E. Z. Z., Mustapha, N. F., Rahim, N. A., Abdullah., S. N. S. (2020). Penterjemahan idiom Arab-Melayu melalui google translate: apakah yang 
perlu dilakukan? GEMA Online® Journal of Language Studies, 20(3), 156180. https://doi.org/http://doi.org/10.17576/gema-2020-2003-10

Abualadas, O. A. (2020). Conversational maxims in fiction translation: New insights into cooperation, characterization, and style. Indonesian Journal of Applied Linguistics, 9(3), 637-645. https://doi.org/Doi: 10.17509/ijal.v9i3.23214

Al-Farisi, M. Z. (2017). Ketedasan terjemahan ayat-ayat imperatif bernuansa Budaya. El Harakah, 19(2), 159-176. https://doi.org/http://dx.doi.org/10.18860/el.v19i2.3934

Al Farisi, M. Z. (2018). The impact of techniques and translation ideology on the clarity of pragmatic meanings translation of the qur'anic imperative verses. Indonesian Journal of Applied Linguistics, 7(3), 676-686. https://doi.org/Doi: 10.17509/ijal.v7i3.9818

Al Farisi, M. Z. (2020). The impact of using foreignization and domestication on the translation accuracy of the quranic metaphor (kinayah) verses. Scientific Journal of KFU (Humanities and Management Sciences), 21(2), 319-332. https://doi.org/https://doi.org/10.37575/h/rel/1966

Alawiyah, N. L., Royani, A., \& Nawawi, M. (2016). Terjemahan teks akademik mahasiswa program studi pendidikan bahasa Arab. Arabiyat: Jurnal Pendidikan Bahasa Arab Dan Kebahasaaraban, 3(2), 218 - 230. https://doi.org/http://dx.doi.org/10.15408/a.v3i2.4642

Ardi, H. (2016). The impact of the translation techniques toward the quality of translation: a case study on a social text. Humanus, 15(2), 142-153. https://doi.org/https://doi.org/10.24036/jh.v15i2.6564

Dhyaningrum, A., Nababan, M. R., \& D. (2016). Analisis teknik penerjemahan dan kualitas terjemahan kalimat yang mengandung ungkapan satire dalam novel the 100-year-old man who climbed out of the window and disappeared. . . Prasasti Journal of Linguistics, 1(2), 210-229. https://doi.org/https://doi.org/10.20961/prasasti.v1i2.1074

Hatmiati. \& Husin. (2018). Budaya dalam penerjemahan bahasa. Jurnal Al-Mi'yar, 1(2), 39-54. https://doi.org/http://dx.doi.org/10.35931/am.v1i2.43

Iskandar, F. (2016). Translation accuracy of English idiomatic expression into Indonesian in 'Big Hero 6' film subtitle by Lebah Ganteng. Al-Turas, 22(2), 353-375. https://doi.org/DOI : 10.5281/zenodo.556810

Larson, M. L. (1998). Meaning - Based Translation: A Guide to Cross - Language Equivalence . (Second Edition). In USA: University Press of America, Inc. University press of America.

Maulana, D. (2019). Analisis kalimat perintah (amr) pada surah yāsīn dalam terjemahan Al-qur'an bacaan mulia hbj. ALSUNIYAT: Jurnal Penelitian Bahasa, Sastra, Dan Budaya Arab, 2(1), 1-14. https://doi.org/https://doi.org/ 10.17509/alsuniyat.v2i1.24348

Maulana, D. (2019). Realisasi Penerjemahan Ungkapan-ungkapan Tabu dalam 
Alquran: Studi Deskriptif Analitik atas Terjemahan Ungkapan-Ungkapan Persetubuhan dalam Terjemah Muhammad Thalib. Tesis tidak diterbitkan. SPS Pendidikan Bahasa Arab: Universitas Pendidikan Indonesia.

Maulana, D., \& Sanusi, A. (2020). Analisis Kesalahan Morfosemantik Pada Teks Terjemahan Siswa Madrasah Aliyah Darussalam Bogor. Indonesian Language Education and Literature, 5(2), 137-146. https://doi.org/10.24235/ileal.v5i2.3837

Mukhlis, R., Nasimah, A., \& L. A. R. (2020). Terjemahan teks keagamaan: tinjauan dari sudut konsep kebolehterjemahan. Journal of Social Science and Humanities, 17(4), 78-89.

Nababan, M., Nuraeni, A., \& S. (2012). Pengembangan model penilaian kualitas terjemahan. Kajian Linguistik Dan Sastra, 24(1), 39-57.

Newmark, P. (1981). Approaches to translation. Pergamon Press.

Raoufkazemi, F., Khorsand, M., Asl, M. P., \& Amirdabbaghian, A. (2020). Expertise and Explicitation in English Translations of the Holy Quran. 3L: The Southeast Asian Journal of English Language Studies, 26(3), 154 - 169. https://doi.org/http://doi.org/10.17576/3L-2020-2603-12

Richards, J. C., \& Richard, S. (2002). Longman dictionary of language teaching and applied linguistics, 3rd Ed. Pearson Education Limited.

Sakri, A. (2003). Bangun kalimat bahasa Indonesia. ITB.

Sakri, Adjat. (1994). Bangun Kalimat Bahasa Indonesia. ITB.

Sanusi, A. (2019). The Quality Translation Analysis of Student Qirāah Text. Arabi: Journal of Arabic Studies, 4(1), 11-20. https://doi.org/http://dx.doi.org/10.24865/ajas.v4i1.119

Stark, D., \& Kussmaul, P. (1997). Training the Translator. In Language (Vol. 73, Issue 1). John Benjamins. https://doi.org/10.2307/416645

Sutantohadi, A. (2017). Analisis kualitas terjemahan artikel media oleh mahasiswa prodi d-3 bahasa inggris politeknik. Jurnal Bahasa Inggris Terapan. Jurnal Bahasa Inggris Terapan, 3(1), 14-28. https://doi.org/https://doi.org/10.35313/inggris.v3i1.1276

Syihabuddin. (2016). Penerjemahan teks suci: analisis ketepatan terjemahan istilah kecendekiaan dalam Alquran dan terjemahnya. Jurnal Adabiyyāt, 17(1), 87-109. https://doi.org/https://doi.org/10.14421/ajbs.2016.15105

Yousofi, N. (2014). Describing the errors in the translations of Iranian novice English translators. Procedia Sosial and Behavioral Sciences, 98, 1952-1958. https://doi.org/https://doi.org/10.1016/j.sbspro.2014.03.628

Zamanian, M., \& Heydari, P. (2012). Readability of texts: state of the art. Theory and Practice in Language Studies, 2(1), 43-53. https://doi.org/10.4304/tpls.2.1.43-53 


\section{Copyright Notice}

Authors retain copyright and grant the journal right of first publication with the work simultaneously licensed under a Creative Commons Attribution 4.0 International License that allows others to share the work with an acknowledgement of the work's authorship and initial publication in this journal.

$$
\text { (c) (†) (อ) }
$$

